\title{
Antenatal service utilization among women in South India: a community based cross sectional study
}

\author{
Chethana K., Manjula Anil*, Maria Nelliyanil
}

\begin{abstract}
Department of Community Medicine, A. J. Institute of Medical Sciences and Research Centre, Kuntikana, Mangalore, Karnataka, India
\end{abstract}

Received: 31 December 2019

Accepted: 29 January 2020

\section{*Correspondence:}

Dr. Manjula Anil,

E-mail: manjula_anil2006@yahoo.co.in

Copyright: () the author(s), publisher and licensee Medip Academy. This is an open-access article distributed under the terms of the Creative Commons Attribution Non-Commercial License, which permits unrestricted non-commercial use, distribution, and reproduction in any medium, provided the original work is properly cited.

\section{ABSTRACT}

Background: Antenatal period is important for identifying pregnancy related threats and antenatal care (ANC) is one of the most effective health interventions during this period. It provides a unique opportunity for screening and diagnosis, health promotion and disease prevention. This study assessed the antenatal service utilization pattern and its determinants among women.

Methods: A community based cross sectional study was conducted in the field practice area of a teaching hospital in Mangalore. Study included 142 women who had delivered in the last one year in the study area, selected using snowball sampling method. A pretested semi-structured validated questionnaire was used to collect the data. Predictors of full ANC were identified using univariate analysis and explanatory variables were entered into multivariate regression model to obtain the adjusted odds ratios to find the association between full ANC coverage and its determinants.

Results: Among the participants, $99.3 \%$ registered their pregnancy and $78.9 \%$ had early registration. Majority, $91.5 \%$ had minimum antenatal visits, $83.1 \%$ consumed iron and folic acid supplements for more than three months and tetanus toxoid (TT) coverage was $98.6 \%$. Full ANC coverage was found to be $81 \%$ and unadjusted analysis showed higher odds of full ANC coverage among housewives, primiparous, women in joint family and among literates. However, multi variable analysis revealed literacy as the major determinant of full ANC.

Conclusions: In the present study, majority of the women had adequate antenatal care utilization. Full antenatal coverage was found to be statistically significant among literate women.

Keywords: Antenatal care, Pregnancy, Utilization

\section{INTRODUCTION}

Pregnancy and childbirth are special events in lives of women and their families. ${ }^{1}$ Antenatal period is important for identifying pregnancy related threats to the mother and unborn baby's health. Antenatal care (ANC) is one of the most effective health interventions for preventing maternal morbidity and mortality. ${ }^{2-4}$ It provides a unique opportunity for screening and diagnosis, health promotion and disease prevention among the pregnant women. ${ }^{5}$ Various services like counselling on nutrition, birth preparedness, delivery care, post-partum care and family planning options after delivery can be emphasized during the antenatal care. ${ }^{1}$ Based on the benefits of ANC, WHO (World Health Organization) endorsed a minimum of four focused antenatal check-ups which was later adopted by developing countries including India. ${ }^{4}$

The sustainable development goals (SDGs) target by 2030 , is to reduce the global maternal mortality ratio (MMR) below 70 maternal deaths per 100,000 live births. ${ }^{6}$ India has registered a 26.9 per cent reduction in 
maternal mortality ratio (MMR) since 2013, with current MMR reaching 122 per 100,000 live births according to the sample registration system (SRS) Bulletin 2015-17. The decline in MMR has been from 77 to 72 per 100,000 live births among southern states according to the SRS report. ${ }^{7}$

Major reasons being implicated for MMR in the country are low literacy levels, inadequate availability of maternal healthcare services, especially emergency obstetric services. A better ANC coverage not only ensures a safer outcome from pregnancy but also provides a platform for improving the health status of mother and baby as both are considered as a single unit. ${ }^{8,9}$ According the National Family Health Survey 2015-16 (NFHS-4) report of Karnataka State, mothers who had full antenatal care (at least four antenatal visits, at least one tetanus toxoid (TT) injection and iron folic acid tablets or syrup taken for 100 or more days) improved to $45.2 \%$ from $28.2 \%$ in NFHS$3 .{ }^{10}$

Utilization of health services is affected by factors like availability, distance, cost and quality of care as well as personal attitudes and socioeconomic conditions. With the above aspects in consideration, a study was conducted to assess the antenatal service utilization pattern and its determinants among women who had delivered in the last one year.

\section{METHODS}

A community based cross sectional study was conducted in the field practice area of a teaching hospital in Mangaluru, Karnataka, from January 2016 to April 2016. Requisite permission from the Institutional Ethics Committee was obtained and informed written consent was obtained from the study participants selected for the study.

Sample size was calculated based on the findings of the pilot study done among 20 mothers showed that, early registration of pregnancy was done by $74.9 \%$ of them. Hence, considering $74.9 \%$ as p, with $95 \%$ confidence interval, an allowable error (d) of $10 \%$ and a nonresponse rate of $10 \%$, the sample size estimated for the study was 142 .

The study was conducted among women who had delivered in the last one year in the study area. Snowball sampling was used to identify such women till the desired sample size was attained. Women who were residing in the area for at least a year were included in the study.

A pretested semi-structured validated questionnaire was administered by the investigator during the house to house survey. The questionnaire contained Part 1 for details of socio demographic profile and Part 2 containing questions regarding antenatal service utilization for the last pregnancy. Full ANC coverage included those mothers who had a minimum of four antenatal visits, at least one tetanus toxoid (TT) injection and iron folic acid tablets or syrup taken for 100 or more days. ${ }^{10}$

\section{Statistical analysis}

Data entry and analysis were done using SPSS (Statistical Package for Social Sciences trail version 16). Results were expressed as frequencies and proportions for categorical variables. Predictors of full ANC were identified using univariate analysis which evaluated the association between full ANC coverage and its determinants like age, type of family, parity, educational status and employment status of the mother. Significant explanatory variables $(\mathrm{p} \leq 0.05)$ obtained from univariate analysis were entered into multivariate regression model to obtain the adjusted odds ratios.

\section{RESULTS}

The mean age of the women was $24.6 \pm 4.0$ years. Majority, $61.3 \%$ were Hindus and $16.2 \%$ of them were illiterate. Most of them, $64.8 \%$ lived in joint families and $14.7 \%$ were employed. It was observed that, $44.4 \%$ were primiparous and only $30.3 \%$ practiced family planning (Table 1).

Table 1: Socio demographic profile and obstetric history of the participants $(n=142)$.

\begin{tabular}{|c|c|c|c|}
\hline Variable & Categories & Numbers & $\%$ \\
\hline \multirow{4}{*}{$\begin{array}{l}\text { Age groups } \\
\text { (years) }\end{array}$} & $\leq 20$ & 19 & 13.4 \\
\hline & $21-25$ & 75 & 52.8 \\
\hline & $26-30$ & 37 & 26.1 \\
\hline & $>30$ & 11 & 7.7 \\
\hline \multirow{2}{*}{ Religion } & Hindu & 87 & 61.3 \\
\hline & Muslim & 55 & 38.7 \\
\hline \multirow{3}{*}{$\begin{array}{l}\text { Educational } \\
\text { status }\end{array}$} & Illiterate & 23 & 16.2 \\
\hline & Primary to SSLC & 94 & 66.3 \\
\hline & PUC and above & 25 & 17.5 \\
\hline \multirow{2}{*}{ Type of family } & Nuclear family & 50 & 35.2 \\
\hline & Joint family & 92 & 64.8 \\
\hline \multirow{2}{*}{$\begin{array}{l}\text { Ownership of } \\
\text { residence }\end{array}$} & Own & 112 & 78.9 \\
\hline & Rental & 30 & 21.1 \\
\hline \multirow{2}{*}{$\begin{array}{l}\text { Employment } \\
\text { status }\end{array}$} & House wife & 121 & 85.3 \\
\hline & Employed & 21 & 14.7 \\
\hline \multirow{3}{*}{ Ration card } & BPL card & 88 & 62.0 \\
\hline & APL card & 45 & 31.7 \\
\hline & Don't have & 09 & 6.3 \\
\hline \multirow{3}{*}{ Parity } & 1 & 63 & 44.4 \\
\hline & 2 & 45 & 31.7 \\
\hline & $\geq 3$ & 34 & 23.9 \\
\hline \multirow{2}{*}{$\begin{array}{l}\text { Family planning } \\
\text { practiced }\end{array}$} & Yes & 43 & 30.3 \\
\hline & No & 99 & 69.7 \\
\hline
\end{tabular}

The mean age at marriage and first child birth were 20 years and 21years, respectively. Mean years of birth spacing among multiparous women was $2.9 \pm 1.9$ years. 
Table 2: Antenatal service utilization among the women $(n=142)$.

\begin{tabular}{|c|c|c|c|}
\hline Variables & Categories & Numbers & $\%$ \\
\hline \multirow{3}{*}{$\begin{array}{l}\text { Registration } \\
\text { of pregnancy }\end{array}$} & $\leq 12$ weeks & 112 & 78.9 \\
\hline & $>12$ weeks & 29 & 20.4 \\
\hline & Not registered & 01 & 0.7 \\
\hline \multirow{3}{*}{$\begin{array}{l}\text { Place of } \\
\text { registration }\end{array}$} & Government & 70 & 49.3 \\
\hline & Private & 71 & 50.0 \\
\hline & Not registered & 01 & 0.7 \\
\hline \multirow{2}{*}{$\begin{array}{l}\text { No. of } \\
\text { Antenatal visit }\end{array}$} & $<4$ & 12 & 8.5 \\
\hline & $\geq 4$ & 130 & $91 . .5$ \\
\hline \multirow{3}{*}{$\begin{array}{l}\text { Iron and folic } \\
\text { acid } \\
\text { supplements }\end{array}$} & $\begin{array}{l}\text { Taken for } 3 \\
\text { months or more }\end{array}$ & 118 & 83.1 \\
\hline & $\begin{array}{l}\text { Taken for less } \\
\text { than 3months }\end{array}$ & 12 & 8.5 \\
\hline & Never taken & 12 & 8.5 \\
\hline \multirow{2}{*}{$\begin{array}{l}\text { Received } \\
\text { Anganwadi } \\
\text { supplements }\end{array}$} & Yes & 94 & 66.2 \\
\hline & No & 48 & 33.8 \\
\hline \multirow{2}{*}{$\begin{array}{l}\text { Received TT } \\
\text { injection* }\end{array}$} & Received & 140 & 98.6 \\
\hline & Not received & 2 & 1.4 \\
\hline \multirow{3}{*}{$\begin{array}{l}\text { Place of } \\
\text { delivery }\end{array}$} & $\begin{array}{l}\text { Government } \\
\text { hospital }\end{array}$ & 77 & 54.2 \\
\hline & Private hospital & 63 & 44.4 \\
\hline & Home & 02 & 1.4 \\
\hline \multirow{2}{*}{$\begin{array}{l}\text { Mode of } \\
\text { delivery }\end{array}$} & Normal & 110 & 77.5 \\
\hline & Caesarean & 32 & 22.5 \\
\hline
\end{tabular}

Among those who practiced family planning method, $53.5 \%$ had undergone tubectomy, $16.3 \%$ used intrauterine devices and $23.3 \%$ used barrier methods and only $7 \%$ used oral contraceptive pills.

Among the participants, $99.3 \%$ registered their pregnancy and $78.9 \%$ had early registration of pregnancy, while $49 \%$ and $50 \%$ of them registered in government and private health care centres, respectively. Majority, $91.5 \%$ had the minimum antenatal visits as recommended. With regard to iron and folic acid (IFA) supplementation, $91.6 \%$ of the women received it; however, $8.5 \%$ of the participants took it for less than 3 months. Most common reason for discontinuing use was that tablets were not palatable $(83.3 \%)$ and among those who never took $(8.5 \%)$ said that they did not want to receive. In this study, only $66.2 \%$ women received the Anganwadi supplements. Most common reason for not receiving was that they did not want to avail it $(62.5 \%)$. Tetanus toxoid (TT) coverage during pregnancy was found to be $98.6 \%$. Two pregnant women did not receive even a single dose of TT injection. Majority, $98.6 \%$ of them had institutional deliveries and $22.5 \%$ delivered by caesarean (Table 2). Most common indication of caesarean was previous caesarean $(53.1 \%)$ followed by fetal complications $(31.3 \%)$.

In this study, full ANC coverage was found to be $81 \%$. Bivariate analysis, revealed that, full ANC coverage was found to be significantly more among women in joint family (91.3\%) compared to nuclear family (62\%). Furthermore, literates were more likely to have full ANC coverage $(89.9 \%)$ compared to illiterates $(34.8 \%)$. Also housewives $(85.1 \%)$ and primiparous women $(90.5 \%)$ were found to be having full ANC coverage as compared to their counter parts, respectively (Table 3).

Table 3: Logistic regression analysis for the predictors of full antenatal coverage among the women $(n=142)$.

\begin{tabular}{|c|c|c|c|c|}
\hline \multirow{2}{*}{ Determinants } & \multicolumn{2}{|l|}{ Full ANC } & \multirow[t]{2}{*}{$\begin{array}{l}\text { Crude odds ratio } \\
\text { (CI) }\end{array}$} & \multirow[t]{2}{*}{$\begin{array}{l}\text { Adjusted odds ratio } \\
\text { (CI) }\end{array}$} \\
\hline & $\begin{array}{l}\text { Yes } \\
\text { No. }(\%)\end{array}$ & $\begin{array}{l}\text { No } \\
\text { No. }(\%)\end{array}$ & & \\
\hline \multicolumn{5}{|l|}{ Age } \\
\hline$>25$ & $42(87.5)$ & $6(12.5)$ & \multirow{2}{*}{$\begin{array}{l}2.01(0.75-5.38) \\
1\end{array}$} & \\
\hline$\leq 25$ & $73(77.6)$ & $21(22.4)$ & & \\
\hline \multicolumn{5}{|l|}{ Type of family } \\
\hline Joint & $84(91.3)$ & $8(8.7)$ & \multirow{2}{*}{$\begin{array}{l}6.43(2.36-16.19)^{*} \\
1\end{array}$} & $2.41(0.80-7.25)$ \\
\hline Nuclear & $31(62.0)$ & $19(38.0)$ & & 1 \\
\hline \multicolumn{5}{|c|}{ Educational status } \\
\hline Literates & 107 (89.9) & $12(10.1)$ & \multirow{2}{*}{$\begin{array}{l}16.71(5.88-47.54)^{*} \\
1\end{array}$} & \multirow{2}{*}{$\begin{array}{l}8.79(2.78-27.79)^{*} \\
1\end{array}$} \\
\hline Illiterates & $8(34.8)$ & $15(65.2)$ & & \\
\hline \multicolumn{5}{|l|}{ Parity } \\
\hline Primipara & $57(90.5)$ & $6(9.5)$ & \multirow{2}{*}{$\begin{array}{l}3.44(1.29-9.15)^{\$} \\
1\end{array}$} & \multirow{2}{*}{$\begin{array}{l}1.98(0.63-6.18) \\
1\end{array}$} \\
\hline Multipara & $58(73.4)$ & $21(26.6)$ & & \\
\hline \multicolumn{5}{|c|}{ Employment status } \\
\hline Housewife & $103(85.1)$ & $18(14.9)$ & \multirow{2}{*}{$\begin{array}{l}4.29(1.58-11.65)^{\$} \\
1\end{array}$} & \multirow{2}{*}{$\begin{array}{l}1.80(0.53-6.20) \\
1\end{array}$} \\
\hline Employed & $12(57.1)$ & $9(42.9)$ & & \\
\hline
\end{tabular}


The unadjusted and adjusted multivariable associations of the factors contributing to full ANC coverage were analysed. It was observed that literates were associated with the higher odds of full ANC coverage (OR: 16.71; 95\% CI: 5.88-47.54). Full ANC coverage was considerably higher among women in joint family (OR: 6.43; 95\% CI: 2.36-16.19). Primiparous women were also associated with an increased odds of full ANC coverage (OR: 3.44; 95\% CI: 1.29-9.15) and women who reported to be house wives had significantly higher odds of full ANC coverage (OR:4.29, 95\% CI:1.58-11.65) (Table 3).

Multi variable analysis revealed that full ANC coverage was higher among literates (AOR: 8.79; CI: 2.78-27.79) as compared to their counterparts and contributed significantly in the final model. Although type of family, parity and employment status were significant covariates in unadjusted analysis for full ANC coverage, it did not contribute to the adjusted model (Table 3). The logistic regression model showed goodness of fit Hosmer Lemeshow $p=0.678$ and Nagarkere $R 2$ of variance was 0.369 .

\section{DISCUSSION}

In the present study, $99.3 \%$ registered their pregnancy and $78.9 \%$ had early registration of pregnancy. Similar to the present study, Narayana Murthy MR et al and Partha $\mathrm{N}$ et al, in their studies in Mysore and Pondicherry, respectively, reported $100 \%$ registration of pregnancy. ${ }^{11,12}$ Study by Tellis SB et al, in the same district reported that $78.3 \%$ had early registration, similar to our study. ${ }^{13}$ However, the early registration was higher in Mysore (98.5\%) and lower in Pondicherry $(60 \%)$ compared to the present study.

Current study revealed that $91.5 \%$ had the minimum 4 antenatal visits, similarly, Tellis SB et al, found that $97.3 \%$ had the minimum number of visits. ${ }^{13}$ Adequate IFA supplementation was received by $83.1 \%$ of the women in this study, which was similar to the other study in the district (82.2\% consumed all the IFA tablets). ${ }^{13}$ Also a study by Pai DV et al, reported, IFA consumption as $85.6 \%$ at udupi. ${ }^{14}$ Injection TT coverage was $98.6 \%$ in this study and $99 \%$ received Injection TT in Tellis SB et al, study. ${ }^{13}$ Similarly TT coverage was high in Mysore, Pondicherry and Udupi. ${ }^{11,12,14}$ However, according to NFHS-4 Dakshina Kannada statistics in urban area, minimum visits $(64.6 \%)$ as well as IFA coverage $(44.4 \%)$ and full ANC coverage $(34.6 \%)$ was less as compared to this study. ${ }^{15}$

This study reveals that full ANC coverage was $81 \%$, while a study in Mysore revealed the full ANC coverage to be $93 \% .^{11}$ According to urban Dakshina Kannada statistics NFHS-4, full ANC coverage was only 34.6\%. ${ }^{15}$ It should be noted that NFHS considers the last birth in the 5 years before the survey, whereas the present study considered last child birth in the past one year. The improved coverage of ANC and utilization pattern may show improved $\mathrm{MCH}$ activities in the study area.

Further, previous studies have concluded that young age, low educational level, high parity, unplanned pregnancy, discontinuity of care, late recognition of pregnancy, behavioral factors, lack of a paid job, cultural practices, support from a social network and lack of knowledge of the health care system are associated with inadequate ANC utilization. ${ }^{16-18}$

In the present study, primiparous, literate women, those living in joint families and being a house wife were positive determinants of full ANC and in further analysis, educational status of the women appeared as the single most important determinant. Similar to the present study a literature review by Ali SA et al, shows that, as parity increases, antenatal care was considered to be less important and higher levels of education tend to positively affect ANC utilization. ${ }^{19}$ Kumar $\mathrm{G}$ et al, in their review of NFHS-4 also reported lowest ANC utilization among those with no formal education and odds of full ANC decreased with increasing birth order. ${ }^{20}$

This study used snowball sampling to select study subjects which may be a limitation of the study as, it may have lead to partipants who have simialr behavious to be selected.

\section{CONCLUSION}

The present study reports that the antenatal care utilization was good among majority of the participants and full antenatal coverage was found to be significantly associated with literacy, with literates having a better coverage. This emphasises the importance of female literacy and its positive effect on women and child health.

\section{ACKNOWLEDGMENTS}

Authors would like to thank the Dean of the Institution, Dr. Ashok Hegde and Head of the Department of Community Medicine, Brig (Dr) Hemant Kumar for their encouragement and support. Authors would also like to acknowledge all the study participants.

Funding: No funding sources

Conflict of interest: None declared

Ethical approval: The study was approved by the Institutional Ethics Committee

\section{REFERENCES}

1. Paudel DP, Nilgar B, Bhandankar M. Antenatal care service utilization and contributing factors: a community-based study in rural Belgaum, Karnataka, India. IOSR J Dent Med Sci. 2013;9(3):25-31.

2. Downe S, Finlayson K, Tuncalp O, Metin Gulmezoglu A. What matters to women: A 
systematic scoping review to identify the processes and outcomes of antenatal care provision that are important to healthy pregnant women. Int J Obstet Gynaecol. 2016;123:529-39.

3. Kassebaum NJ, Barber RM, Bhutta ZA, Dandona L, Gething PW, Hay SI, et al. Global, regional, and national levels of maternal mortality, 1990-2015: A systematic analysis for the Global Burden of Disease Study 2015. Lancet. 2016;388:1775-812.

4. Berhan Y and Berhan A. Antenatal care as a means of increasing birth in the health facility and reducing maternal mortality: A systematic review. Ethiopian J Health Sci. 2014;24:93-104.

5. World Health Organization. Recommendations on Antenatal Care for a Positive Pregnancy Experience; World Health Organization: Geneva, Switzerland, 2016.

6. Sustainable development goals. Goal 3: Ensure healthy lives and promote well-being for all at all ages. Available

https://www.un.org/sustainabledevelopment/health/.

Accessed 15 December 2019.

7. Special Bulletin on Maternal Mortality in India 2015-17. Sample Registration System Office of Registrar General, India. 2019. Available at: http://www.censusindia.gov.in/vital_statistics/SRS_

Bulletins/MMR_Bulletin-2015-17.pdf. Accessed on $15^{\text {th }}$ December 2019.

8. Jat TR, Ng N, San Sebastian M. Factors affecting the use of maternal health services in Madhya Pradesh state of India: a multilevel analysis. Int $\mathrm{J}$ Equity Health. 2011;10:59.

9. Kesterton AJ, Cleland J, Sloggett A, Ronsmans C. Institutional delivery in rural India: The relative importance of accessibility and economic status. BMC Preg Childbirth. 2010;10:30.

10. State Fact Sheet Karnataka. National Family Health survey 4 2015-16. International Institute for Population Sciences, Mumbai. Available at: http://rchiips.org/nfhs/pdf/NFHS4/KA_FactSheet.pd. Accessed 17 December 2019.

11. Narayana Murthy MR, Siddalingappa H, Mishra B. Assessment of utilization of antenatal care services by mothers attending immunization sessions at a primary health centre in Mysore district, Karnataka, India. Int $\mathbf{J}$ Community Med Pub Health. 2016;3:2561-5.

12. Partha N, Lokesh A, Gupta SK, Prabhakaran M. A Study on utilization of antenatal care services among rural women in, Pondicherry district. Indian J Mother Child Health. 2011;13(2):8.

13. Tellis SB, Rent PD, Dmello MK. Utilization of antenatal care and out of pocket expenditure on delivery care in Dakshina Kannada. Int J Community Med Public Health. 2018;5:3553-8.

14. Pai DV, Anjum Z, Kumar A, Shetty A, Mishra S, Kumar U, et al. Utilization of maternal and child health services among migratory/slum dwellers in Udupi municipality area, Karnataka, India. Int J Community Med Public Health. 2018;5:3835-41.

15. District Fact Sheet Dakshina Kannada Karnataka. National Family Health survey 4 2015-16. International Institute for Population Sciences, Mumbai. Available at: http://rchiips.org/nfhs/FCTS/KA/KA_FactSheet_575 _Dakshina\%20Kannada.pdf. Accessed 20 December 2019.

16. Beeckman K, Louckx F, Putman K. Content and timing of antenatal care: predisposing, enabling and pregnancy related determinants of antenatal care trajectories. Eur J Public Health. 2013;23:67-73.

17. Feijen-de Jong EI, Jansen DE, Baarveld F, van der Schans CP, Schellevis FG, Reijneveld SA. Determinants of late and/or inadequate use of prenatal healthcare in high-income countries: a systematic review. Eur J Public Health 2012;22(6):904-13.

18. Heaman M, Bayrampour H, Kingston D, Blondel B, Gissler M, Roth C et al. Migrant women's utilization of prenatal care: a systematic review. Matern Child Health J. 2013;17:816-36.

19. Ali SA, Dero AA, Ali SA, Ali BG. Factors affecting the utilization of antenatal care among pregnant women: a literature review. J Preg Neonatal Med. 2018;2(2):41-5.

20. Kumar G, Choudhary TS, Srivastava A, Upadhyay RP, Taneja S, Bahl R, et al. Utilisation, equity and determinants of full antenatal care in India: analysis from the National Family Health Survey 4. BMC Preg Childbirth. 2019;19(327):1-9.

Cite this article as: Chethana K, Anil M, Nelliyanil M. Antenatal service utilization among women in South India: a community based cross sectional study. Int J Reprod Contracept Obstet Gynecol 2020;9:1110-4. 